\title{
Hubungan status gizi dengan pertumbuhan dan perkembangan balita 1-3 tahun
}

\author{
Setiawati ${ }^{1}$, Erna Rahma Yani², Megah Rachmawati ${ }^{3 *}$ \\ 1,3Program Studi Ilmu Keperawatan Universitas Malahayati Bandar Lampung. \\ *Email: Megahrachmawati1@gmail.com \\ 2Politeknik Kesehatan Kementerian Kesehatan, Malang. Email: erna.rahma_75@yahoo.co.id
}

\begin{abstract}
Relationships between physical growth, mental development and nutritional status in children 1-3 years of age
\end{abstract}

Background: Based on health surveys under the Ministry of Health of the Republic of Indonesia in 2018, the prevalence of delayed gross motor development, social personal, soft motor and language development in children aged $0.5-5.9$ years is still high reaching $11.5 \%$, up to $21,6 \%$, and the prevalence of malnutrition reaches $3.9 \%$. The percentage of malnutrition in Lampung Province is $1.6 \%$ to $12.4 \%$.

Purpose: Knowing relationships between physical growth, mental development and nutritional status in children $1-3$ years of age.

Method: A quantitative research, using a cross-sectional approach with a population was mothers of children aged 1-3 years at the Palapa Health Center in Bandar Lampung City with a sample of 203 toddlers, using random sampling with proportional random sampling technique. Data collection techniques were used by observing toddlers and filling in the Pre-Screening Questionnaire of Development (KPSP) by their mothers. The statistical test used was the Chi Square test.

Results: The frequency distribution of toddlers with adequate nutrition status of 104 toddlers (51.2\%), appropriate in physical growth as many as 134 toddlers (66.0\%), and appropriate in mental development was 142 toddlers $(70.0 \%)$. There is a relationship of nutritional status with the physical growth ( $p$ value $0.001, O R 2.8$ ). There is a relationship of nutritional status with the mental development ( $p$ value 0.007, OR 2.4 )

Conclusion: There is a relationships between physical growth, mental development and nutritional status in children 1-3 years of age. Suggestions for health workers are expected to further improve the monitoring of the nutritional status of children and conduct routine early detection of deviations of child development

\section{Keywords: Physical growth; Mental development; Nutritional status; Children 1-3 years of age}

Pendahuluan: Berdasarkan survey kesehatan dibawah Kementerian Kesehatan Republik Indonesia tahun 2018, prevalensi keterlambatan perkembangan motorik kasar, sosial personal, motorik halus dan perkembangan bahasa pada anak usia 0,5-5,9 tahun masih tinggi mencapai $11,5 \%$, sampai dengan $21,6 \%$, dan prevalensi gizi buruk hingga mencapai 3,9\%. Provinsi Lampung persentase gizi buruk sebesar 1,6\%, dan gizi kurang 12,4\%.

Tujuan: Diketahui hubungan status gizi dengan pertumbuhan dan perkembangan balita 1-3 tahun di Puskesmas Palapa Kota Bandar Lampung tahun 2019.

Metode: Penelitian kuantitatif, menggunakan pendekatan cross sectional dengan populasi dalam para ibu yang mempunyai balita 1-3 tahun di Puskesmas Palapa Kota Bandar Lampung dengan sampel 203 balita, menggunakan random sampling dengan teknik Proportional random sampling. Tehnik pengumpulan data menggunakan dengan cara mengobservasi balita dan pengisian data kuesioner KPSP oleh ibu yang mempunyai balita yang dijadikan sebagai responden. Uji statistik yang digunakan adalah uji Chi Square.

Hasil: Distribusi frekuensi balita dengan asupan gizi cukup yaitu sebanyak 104 balita $(51,2 \%)$, pertumbuhan kotegori sesuai sebanyak 134 balita $(66,0 \%)$, perkembangan yang kategori tidak menyimpang sebanyak 142 balita $(70,0 \%)$. Ada hubungan status gizi dengan pertumbuhan balita 1-3 tahun ( $p$ value $0,001, O R 2,8$ ) Ada hubungan status gizi dengan perkembangan balita 1-3 tahun ( $p$ value 0,007, OR 2,4)

Simpulan: Adanya hubungan status gizi dengan pertumbuhan dan perkembangan balita 1-3 tahun di Puskesmas Palapa Kota Bandar Lampung tahun 2019. Saran bagi tenaga kesehatan diharapkan lebih

Setiawati', Megah Rachmawati ${ }^{3 *}$ Program Studi llmu Keperawatan Universitas Malahayati Bandar Lampung. *Email: Megahrachmawatil@gmail.com

Erna Rahma Yani ${ }^{2}$ Politeknik Kesehatan Kementerian Kesehatan, Malang. Email: erna.rahma_75@yahoo.co.id 
Hubungan status gizi dengan pertumbuhan dan perkembangan balita 1-3 tahun

meningkatkan lagi pemantauan terhadap status gizi anak dan melakukan deteksi dini secara rutin terhadap penyimpangan perkembangan anak.

\section{Kata Kunci: Status gizi; Pertumbuhan; Perkembangan; Balita}

\section{PENDAHULUAN}

Masa anak-anak merupakan masa kehidupan yang sangat penting dan perlu perhatian yang serius. Masa ini berlangsung proses tumbuh kembang yang sangat pesat yaitu pertumbuhaan fisik, perkembangan psikomotorik, mental dan sosial. Salah satu faktor penting yang mempengaruhi tumbuh kembang anak adalah faktor gizi. Kekurangan gizi pada anak akan berdampak pada keterbatasan pertumbuhan, kerentanan terhadap infeksi, dan akhirnya dapat menghambat perkembangan anak sehingga anak perlu memperoleh gizi dari makanan sehari-hari dalam jumlah yang tepat dan kualitas baik (Indriati, \& Murpambudi, 2016 ; Meilani, \& Zulaikha, 2018).

Perkembangan anak merupakan segala perubahan yang terjadi pada anak, dilihat dari berbagai aspek, antara lain aspek motorik, emosi, kognitif, dan psikososial (bagaimana anak berinteraksi dengan lingkungannya). Salah satu perkembangan batita adalah perkembangan motorik, secara umum perkembangan motorik dibagi menjadi dua yaitu motorik kasar dan motorik halus. Motorik kasar adalah bagian dari aktivitas motor yang melibatkan keterampilan otot-otot besar. Gerakan-gerakan seperti tengkurap, duduk, merangkak, dan mengangkat leher. Gerakan inilah yang pertama terjadi pada 3 tahun pertama usia anak. Motorik halus merupakan aktivitas keterampilan yang melibatkan gerakan otot-otot kecil seperti, menggambar, meronce manik, menulis, dan makan. Kemampuan motorik halus ini berkembang setelah kemampuan motorik kasar si kecil berkembang (Soetjiningsih, 2012).

Menurut UNICEF tahun 2011 didapat data masih tingginya angka kejadian gangguan pertumbuhan dan perkembangan pada anak usia balita khususnya gangguan perkembangan motorik didapatkan $(27,5 \%)$ atau 3 juta anak mengalami gangguan. Di dunia, lebih dari 200 juta anak di bawah 5 tahun gagal mencapai potensi dalam perkembangan kognitif. Di Indonesia, prevalensi anak yang pendek atau stunting pada balita meningkat dari $35,6 \%$ pada tahun 2010 menjadi $37,2 \%$ pada tahun 2013. Prevalensi keterlambatan perkembangan pada anak usia 0,5 - 5,9 tahun berdasarkan studi SEANUT adalah
21,6 persen, yang terdiri dari 11,5 persen, $14,5 \%$, $11,8 \%$ dan $15,8 \%$ masing-masing untuk perkembangan motorik kasar, sosial personal, motorik halus dan perkembangan bahasa (United Nations Children's Fund, 2011; Harahap, Budiman, \&Widodo, 2018).

Status gizi balita usia 1-3 tahun dapat diukur dengan indeks berat badan per umur $(\mathrm{BB} / \mathrm{U})$, tinggi badan per umur (TB/U) dan berat badan per tinggi badan (BB/TB). Hasil pengukuran status gizi PSG tahun 2016 dengan indeks BB/U pada balita 0-59 bulan, mendapatkan persentase gizi buruk sebesar $3,4 \%$, gizi kurang sebesar $14,4 \%$ dan gizi lebih sebesar 1,5\%. Angka tersebut tidak jauh berbeda dengan hasil PSG 2015, yaitu gizi buruk sebesar $3,9 \%$, gizi kurang sebesar $14,9 \%$ dan gizi lebih sebesar $1,6 \%$. Sedangkan berdasarkan Riskesdas tahun 2018 diketahui bahwa prevalensi gizi kurang sebesar $13,8 \%$ dan gizi buruk menjadi 3,9\%. Provinsi dengan gizi buruk dan kurang tertinggi tahun 2016 adalah Nusa Tenggara Timur $(28,2 \%)$ dan terendah Sulawesi Utara $(7,2 \%)$, sedangkan untuk Provinsi Lampung persentase gizi buruk sebesar 1,6\%, gizi kurang sebesar 12,4\% (Kementerian Kesehatan Republik Indonesia, 2017).

Hasil Riskesdas tahun 2013 menunjukkan Prevalensi status gizi balita (BB/U) di Kota Bandar Lampung untuk gizi buruk $3.5 \%$, gizi kurang $12.3 \%$, gizi baik $78.2 \%$ dan gizi lebih $5.9 \%$. Berdasarkan profil kesehatan Kota Bandar lampung tahun 2014, penemuan kasus gizi buruk hanya 6 kasus. Dan berdasarkan Laporan tahunan program gizi Kota Bandar Lampung Tahun 2019 diketahui bahwa pencapaian kenaikan berat badan dari balita yang datang menimbang ke Posyandu (N/D) setiap bulannya mencapai 83,25\% (62.039 dari 74.519 balita) dengan capaian terendah adalah Puskesmas Palapa yaitu sebesar 63,04\% (1.561 dari 2.476 balita) (Kementerian Kesehatan Republik Indonesia, 2013; Sapitri, Yudiernawati, \& Maemunah, 2018).

Status gizi yang buruk pada balita dapat menimbulkan pengaruh yang sangat menghambat fisik, mental maupun kemampuan berfikir yang pada akhirnya akan menurunkan kemampuan kerja balita dalam aktivitasnya. Kekurangan gizi

Setiawati', Megah Rachmawati ${ }^{3 *}$ Program Studi llmu Keperawatan Universitas Malahayati Bandar Lampung.

*Email: Megahrachmawatil@gmail.com

Erna Rahma Yani ${ }^{2}$ Politeknik Kesehatan Kementerian Kesehatan, Malang. Email: erna.rahma_75@yahoo.co.id 
Hubungan status gizi dengan pertumbuhan dan perkembangan balita 1-3 tahun

dapat menimbulkan kekacauan struktur dan metabolisme sedemikian rupa, sehingga pertumbuhan dan perkembangan untuk melaksanakan tugas saraf menjadi sangat terbatas. Jika pertumbuhan dan perkembangan otak terganggu anak sudah menjadi besar, anak tidak dapat melaksanakan tugas- tugas intelektual yang seharusnya dapat dilakukan bila perkembangan normal tidak terganggu oleh rusaknya perkembangan otak karena kurang gizi (Supariasa, 2012).

Hasil penelitian tentang Hubungan Status Gizi Dengan Perkembangan Balita Usia 1-3 Tahun Di Wilayah Kerja Puskesmas Jetis Kota Yogyakarta menunjukkan ada hubungan status gizi dengan perkembangan balita usia 1-3 tahun di Wilayah kerja Puskesmas Jetis Kota Yogyakarta, yang berarti semakin baik gizi balita maka perkembangan balita pun semakin baik ( $p$ value 0,000).( Solechah 2017)

Hasil presurvey terhadap 10 balita 1-3 tahun diketahui sebanyak 4 Balita dengan status gizi kurang, dan sebanyak 3 orang mengalami perkembangan yang terlambat, yaitu belum mampu menyusun kalimat pada usia 2 tahun, mengambar mengikuti garis. Oleh karena itu peneliti tertarik untuk meneliti tentang hubungan gizi dengan pertumbuhan dan perkembangan balita 1-3 tahun di Puskesmas Palapa Kota Bandar Lampung Tahun 2019.

\section{METODE PENELITIAN}

Jenis penelitian kuantitatif dilakukan pada tanggal 20 juni sampai 20 juli 2019 di Puskesmas Palapa Kota Bandar Lampung. Penelitian ini menggunakan desain analitik dengan pendekatan cross sectional. Populasinya adalah balita 1-3 tahun beserta orang tuanya/ibunya yang dijadikan sebagai respondennya/sampel sejumlah 203 responden. Sebagai variabel independennya adalah status gizi dan variabel terikatnya pertumbuhan dan perkembangan balita 1-3 tahun dengan memakai uji statistik Chi square.

Cara pengumpulan data dengan dua cara; pertama dengan menggunakan lebar observasi untuk melihat pertumbuhan balita tersebut dengan menggunakan alat timbangan berat badan dan meteran. Kriteria hasilnya: sesuai (jika BB/PB atau BB/TB - 2 SD s.d + 2 SD) dan tidak sesuai (jika $\mathrm{BB} / \mathrm{PB}$ atau $\mathrm{BB} / \mathrm{TB}<-2 \mathrm{SD}$ ).

Pengumpulan data selanjutnya yaitu pengisian data oleh orangtua/ibu dari balita tersebut meliputi; pengisian KPSP untuk melihat perkembangan balita dengan kriteria hasil: tidak Menyimpang (Jawaban YA 9-10) dan menyimpang (jawaban Ya $\leq 8$ ). Dan yang terakhir untuk melihat status gizi balita mengisi Formulir Food recall wawancara asupan nurisi dengan kriteria hasil kategoti cukup (80-100\% AKG) dan kategori buruk (< 80\% AKG).

Food recall menggunakan metode Nutrisisurvey adalah sebuah software yang di buat oleh Jurgen Erdadt dan Reiner Gross. Nutrisisurvey di kembangkan tahun 2005 dan versi terbaru keluar tahun 2007 dan kedua versi tersebut berbahasa inggris (Rahmadi, 2012). 
HASIL

Tabel 1. Distribusi Karakteristik Balita $\mathrm{N}=203$

\begin{tabular}{lcc}
\hline Variabel & Frekuensi (f) & Persentasi (\%) \\
\hline Usia & 102 & 50.2 \\
$-\quad$ 12-23 Bulan & 101 & 49.8 \\
$-\quad$ 24-35 Bulan & & \\
Jenis Kelamin & 103 & 50.7 \\
- Laki-laki & 100 & 49.3 \\
- Perempuan & & \\
Pertumbuhan & 134 & 66.0 \\
- Sesuai & 69 & 34.0 \\
- Tidak sesuai & & \\
Perkembangan & 61 & 30.0 \\
- Menyimpang & 142 & 70.0 \\
- Tidak Menyimpang & & \\
Asupan Gizi & 104 & 51.2 \\
- Baik & 99 & 48.8 \\
\hline$\quad$ Buruk & & \\
\hline
\end{tabular}

Berdasarkan tabel 1 diketahui bahwa balita berusia 12-23 bulan sebanyak 102 balita (50,2\%). Berjenis kelamin laki-laki yaitu sebanyak 103 balita $(50,7 \%)$. balita dengan pertumbuhan sesuai yaitu sebanyak 134 balita $(66,0 \%)$, sedangkan yang pertumbuhan tidak sesuai sebanyak 69 balita $(34,0 \%)$. Balita dengan perkembangan tidak menyimpang yaitu sebanyak 142 balita $(70,0 \%)$, sedangkan yang perkembangan menyimpang sebanyak 61 balita $(30,0 \%)$. Balita dengan asupan gizi baik yaitu sebanyak 104 balita $(51,2 \%)$, sedangkan yang asupan gizi buruk sebanyak 99 balita $(48,8 \%)$.

Tabel 2.Hubungan Status Gizi dengan Pertumbuhan dan Perkembangan Balita 1-3 Tahun N = 203

\begin{tabular}{|c|c|c|c|c|c|c|c|c|}
\hline \multirow{3}{*}{ Variabel } & \multicolumn{4}{|c|}{ Asupan Gizi } & \multirow{2}{*}{\multicolumn{2}{|c|}{ Total }} & \multirow{3}{*}{$p$-value } & \multirow{3}{*}{$\begin{array}{c}\text { OR } \\
\text { (Cl 95\%) }\end{array}$} \\
\hline & \multicolumn{2}{|c|}{ Baik } & \multicolumn{2}{|c|}{ Buruk } & & & & \\
\hline & $\mathrm{n}$ & $\%$ & $\mathrm{n}$ & $\%$ & \multicolumn{2}{|c|}{ n $\%$} & & \\
\hline \multicolumn{9}{|l|}{ Pertumbuhan } \\
\hline -Sesuai & 80 & 39.4 & 54 & 26.7 & 134 & 66.0 & 0,001 & $2,8(1,5-5,1)$ \\
\hline -Tidak Sesuai & 24 & 11.8 & 45 & 22,1 & 69 & 34.0 & & \\
\hline \multicolumn{9}{|l|}{ Perkembangan } \\
\hline -Tidak Menyimpang & 82 & 40,4 & 60 & 29,6 & 142 & 70.0 & & \\
\hline -Menyimpang & 22 & 10.8 & 39 & 19,2 & 61 & 30.0 & 0,001 & $2,4(1,3-4,5)$ \\
\hline
\end{tabular}

Hasil penelitian didapatkan bahwa dari 104 balita dengan asupan gizi baik sebanyak 80 balita $(39,4 \%)$ memiliki pertumbuhan yang sesuai dan 24 balita $(11,8 \%)$ memiliki pertumbuhan yang tidak sesuai, sedangkan dari 99 balita dengan asupan gizi buruk, sebanyak 54 balita $(26,7 \%)$ memiliki

Setiawati', Megah Rachmawati ${ }^{3 *}$ Program Studi llmu Keperawatan Universitas Malahayati Bandar Lampung. *Email: Megahrachmawatil@gmail.com

Erna Rahma Yani Politeknik Kesehatan Kementerian Kesehatan, Malang. Email: erna.rahma_75@yahoo.co.id 
pertumbuhan yang sesuai dan 45 balita $(22,1 \%)$ memiliki pertumbuhan yang tidak sesuai. Hasil uji chi square didapatkan nilai $p$ value $0,001(0,001<$ a 0,05 ) sehingga dapat disimpulkan secara statistik dengan derajat kepercayaan 95\%, diyakini terdapat hubungan gizi dengan pertumbuhan balita 1-3 tahun. Sedangkan hasil uji OR diperoleh nilai 2,8 (Cl 95\% 1,5-5,1), artinya balita dengan asupan gizi buruk berisiko 2,8 kali lebih besar untuk memiliki pertumbuhan yang tidak sesuai dibandingkan balita dengan asupan gizi baik.

Sedangkan untuk perkembangan didapatkan bahwa dari 104 balita dengan asupan gizi baik sebanyak 82 balita $(40,4 \%)$ memiliki perkembangan yang tidak menyimpang dan 22 balita $(10,8 \%)$ memiliki perkembangan yang menyimpang, sedangkan dari 99 balita dengan asupan gizi buruk, sebanyak 60 balita $(29,6 \%)$ memiliki perkembangan yang tidak menyimpang dan sebanyak 39 balita $(19,2 \%)$ memiliki perkembangan yang menyimpang. Hasil uji chi square didapatkan nilai $p$ value $0,007 \quad(0,007<$ a0,05) dan dapat disimpulkan secara statistik dengan derajat kepercayaan 95\%, diyakini terdapat hubungan gizi dengan perkembangan balita 1-3 tahun di Puskesmas Palapa Kota Bandar Lampung tahun 2019. Sedangkan hasil uji OR diperoleh nilai 2,4 (Cl 95\% 1,3-4,5), artinya balita dengan asupan gizi buruk berrisiko 2,4 kali lebih besar untuk memiliki perkembangan yang menyimpang dibandingkan balita dengan asupan gizi baik.

\section{PEMBAHASAN}

\section{Pertumbuhan}

Hasil penelitian menunjukan bahwa distribisi frekuensi balita dengan pertumbuhan tidak menyimpang yaitu sebanyak 134 balita $(66,0 \%)$, sedangkan yang pertumbuhan menyimpang sebanyak 69 balita $(34,0 \%)$. Pertumbuhan adalah bertambahnya ukuran dan jumlah sel serta jaringan interselular, berarti bertambahnya ukuran fisik dan struktur tubuh sebagian atau keseluruhan, sehingga dapat diukur dengan satuan palapa dan berat (Kementerian Kesehatan Republik Indonesia, 2016). Ada beberapa faktor yang bisa mempengaruhi pertumbuhan pada anak diantaranya adalah asupan makanan, penyakit infeksi, dan pola pengasuhan anak. Anak yang mendapat makanan yang baik baik tetapi sering diserang penyakit infeksi dapat berpengaruh terhadap status gizinya. Begitu juga sebaliknya, anak yang makanannya tidak baik baik, daya tahan tubuhnya pasti lemah dan pada akhirnya mempengaruhi status gizinya. Pola pengasuhan anak, berupa sikap dan perilaku ibu, atau pengasuh lain dalam hal kedekatannya dengan anak, memberikan makan, merawat, kebersihan, kasih sayang dan sebagainya.

Hasil penelitian sebelumnya juga menemukan kategori pertumbuhan normal yaitu sebanyak 49 anak $(89,1 \%)$, sementara yang dalam kategori pertumbuhan buruk sebanyak 6 anak (10,9\%) (Setiasih, 2011). Menurut peneliti berdasarkan hasil tersebut dapat dilihat masih cukup banyak balita yang belum sesuai dengan harapan. Padahal pertumbuhan di masa balita akan menjadi salah satu faktor penentu untuk pertumbuhan dimasa berikutnya. Sehingga diperlukan intervensi yang baik dari petugas kesehatan dan keluarga.

\section{Perkembangan}

Hasil penelitian menunjukan bahwa distribisi frekuensi balita dengan perkembangan sesuai yaitu sebanyak 142 balita $(70,0 \%)$, sedangkan yang perkembangan tidak sesuai sebanyak 61 balita $(30,0 \%)$. Perkembangan adalah bertambah sempurnanya fungsi organ tubuh dan keterampilan termasuk emosi, intelektual, dan tingkah laku sebagai hasil interaksi dengan lingkungan yang sifatnya kualitatif (Jahja, 2011; Solechah, 2017). Aspek perkembangan ini sifatnya kualitatif, yaitu pertambahan kematangan fungsi dari masingmasing bagian tubuh, yang diawali dengan jantung bisa berdenyut memompa darah, kemampuan bernafas sampai anak mempunyai kemampuan tengkurap, duduk, berjalan, bicara, memungut benda-benda disekelilingnya, serta kemampuan emosi dan social anak. Tahap perkembangan awal akan menentukan perkembangan selanjutnya.

Hasil penelitian sebelumnya tentang Hubungan Status Gizi Dengan Perkembangan Balita Usia 1-3 Tahun Di Wilayah Kerja Puskesmas Jetis Kota Yogyakarta menunjukkan kategori perkembangan mayoritas balita dengan kategori perkembangan yang sesuai sebanyak 119 balita $(73,4 \%)$ (Solechah,2017). Dalam penelitian ini

Setiawati', Megah Rachmawati ${ }^{3 *}$ Program Studi llmu Keperawatan Universitas Malahayati Bandar Lampung.

*Email: Megahrachmawatil@gmail.com

Erna Rahma Yani ${ }^{2}$ Politeknik Kesehatan Kementerian Kesehatan, Malang. Email: erna.rahma_75@yahoo.co.id 
masih dijumpai sebagian anak $(30,0 \%)$ dengan perkembangan menyimpang. Apabila perkembangan anak menyimpang maka harus dilakukan rujukan, dan apabila perkembangan anak meragukan maka perlu dilakukan uji ulang dalam 1-2 minggu untuk menghilangkan faktor sesaat seperti rasa takut, keadaan sakit atau kelelahan, namun rujukan dan tes tersebut tidak dilakukan oleh peneliti, hal tersebut merupakan keterbatasan dari penelitian ini. Kondisi ini memerlukan pengukuran lanjutan setelah dilakukan intervensi.

\section{Asupan Gizi}

Hasil penelitian menunjukan bahwa distribisi frekuensi balita dengan asupan gizi baik yaitu sebanyak 104 balita $(51,2 \%)$, sedangkan yang asupan gizi buruk sebanyak 99 balita $(48,8 \%)$. Gizi (nutrients) merupakan ikatan kimia yang diperlukan tubuh untuk melakukan fungsinya, yaitu menghasilkan energi, membangun dan memelihara jaringan, serta mengatur prosesproses kehidupan. Disamping untuk kesehatan, gizi dikaitkan dengan potensi ekonomi seseorang, karena gizi berkaitan dengan perkembangan otak, kemampuan belajar, dan produktivitas kerja (Almatsier, 2012). Hasil penelitian sebelumnya yang menunjukkan sebagian besar anak-anak di wilayah ini mengkonsumsi makanan yang mengandung asupan nutrisi yang baik, anak di wilayah ini sebagian besar makan 3 kali dalam sehari dengan porsi $1 / 2$ porsi sedang untuk sekali makan, sebagian besar anak mengkonsumsi susu formula setiap hari dan semua balita juga diberikan makanan selingan setiap hari (Azis, 2018).

Asupan energi yang tidak menbaiki kebutuhan dapat menyebabkan terjadinya ketidakseimbangan energi. Ketidakseimbangan energi secara berkepanjangan menyebabkan terjadinya masalah gizi seperti keburukan energi kronis (KEK) serta berdampak pada perubahan berat badan seseorang. Balita dengan tingkat asupan energi yang rendah mempengaruhi pada fungsi dan struktural perkembangan otak serta dapat mengakibatkan pertumbuhan dan perkembangan kognitif yang terhambat. Energi yang berasal dari makanan dapat diperoleh dari beberapa zat gizi makro yaitu karbohidrat, protein dan lemak. Energi memiliki fungsi sebagai penunjang proses pertumbuhan, metabolisme tubuh dan berperan dalam proses aktivitas fisik.
Dalam penelitian ini masih ditemukan balita dengan asupan gizi buruk yang sebanyak 99 balita $(48,8 \%)$. Hal ini dapat disebabkan oleh beberapa faktor antara lain karena buruknya pengetahuan ibu tentang kebutuhan gizi balita, sehingga ibu buruk memberikan makan beraneka ragam pada balita. Biasanya ibu hanya memberi makan balitanya dengan menu yang sama, yaitu ayam, atau telur, jarang diberikan sayur atau buah. Atau bahkan ibu tidak memberikan asupan makan yang baik karena balita masih minum susu, yang dianggap ibu telah menbaiki kebutuhan harian balita.

\section{Hubungan Asupan Gizi dengan Pertumbuhan}

Hasil penelitian didapatkan nilai $p$ value 0,001 , artinya lebih kecil dibandingkan dengan nilai alpha $(0,001<0,05)$. Dengan demikian dapat disimpulkan secara statistik dengan derajat kepercayaan $95 \%$, diyakini terdapat hubungan gizi dengan pertumbuhan balita 1-3 tahun. Sedangkan hasil uji OR diperoleh nilai 2,8 (CI 95\% 1,5-5,1), artinya balita dengan asupan gizi buruk berrisiko 2,8 kali lebih besar untuk memiliki pertumbuhan yang tidak sesuai dibandingkan balita dengan asupan gizi baik. Pertumbuhan adalah bertambahnya jumlah dan ukuran sel serta jaringan interselular, yang berarti bertambahnya ukuran fisik dan struktur tubuh sebagian atau keseluruhan, sehingga dapat diukur dengan satuan palapa dan berat (Kementerian Kesehatan Republik Indonesia, 2016). Konsumsi makanan merupakan faktor utama yang berperan terhadap pertumbuhan seseorang.

Hasil penelitian sebelumnya juga menemukan adanya hubungan antara asupan energi dengan status pendek pada anak di Nakhon Pathom, Bangkok oleh (Suthutvoravut, 2006). Penelitian lain juga menemukan hubungan yang bermakna antara konsumsi makanan yang diberikan dengan pertumbuhan anak balita di Posyandu Cempaka Desa Ngrembel Kelurahan Gunung Pati Kota Semarang $(p=0,000)$ (Setiasih, 2011).

Menurut peneliti balita dengan tingkat asupan energi yang rendah mempengaruhi pada fungsi dan struktural perkembangan otak serta dapat mengakibatkan pertumbuhan dan perkembangan kognitif yang terhambat. Energi yang berasal dari makanan dapat diperoleh dari beberapa zat gizi makro yaitu karbohidrat, protein dan lemak. Energi memiliki fungsi sebagai penunjang proses

Setiawati', Megah Rachmawati ${ }^{3 *}$ Program Studi llmu Keperawatan Universitas Malahayati Bandar Lampung.

*Email: Megahrachmawatil@gmail.com

Erna Rahma Yani Politeknik Kesehatan Kementerian Kesehatan, Malang. Email: erna.rahma_75@yahoo.co.id 
pertumbuhan, metabolisme tubuh dan berperan dalam proses aktivitas fisik. Jika balita tidak diberikan asupan yang sesuai maka otot dan jaringan tubuh tidak dapat berfungsi dengan optimal.

\section{Hubungan Asupan Gizi dengan Perkembangan}

Hasil penelitian didapatkan nilai $p$ value 0,007 , artinya lebih kecil dibandingkan dengan nilai alpha $(0,007<0,05)$. Dengan demikian dapat disimpulkan secara statistik dengan derajat kepercayaan $95 \%$, diyakini terdapat hubungan gizi dengan perkembangan balita 1-3 tahun di Puskesmas Palapa Kota Bandar Lampung tahun 2019. Sedangkan hasil uji OR diperoleh nilai 2,4 (Cl 95\% 1,3-4,5), artinya balita dengan asupan gizi buruk berpeluang 2,4 kali lebih besar untuk memiliki perkembangan yang menyimpang dibandingkan balita dengan asupan gizi baik.

Asupan gizi merupakan kebutuhan anak yang berperan dalam proses tumbuh kembang terutama tumbuh kembang otak. Asupan zat gizi yang penting untuk fungsi motorik meliputi energi, protein, besi dan seng. Energi dan protein berperan dalam proses proliferasi,difersensiasisel, dan synaptogenesis (Susanty, \& Margawati, 2012). Besi berperan dalam sistesis monoamine, metabolisme energi di neuron dan sel glia serta mielinisasi. Seng berperan dalam sistesis DNA dan pelepasan neurotransmitter. Didapatkan hasil uji korelasi menunjukan ada hubungan asupan energi dengan perkembangan kasar sebesar 20\%, sedangkan untuk asupan protein sebesar $27 \%$ yang berhubungan dengan perkembangan motorik kasar anak. Hasil penelitian tentang Hubungan Status Gizi Dengan Perkembangan Balita Usia 1-3 Tahun Di Wilayah Kerja Puskesmas Jetis Kota Yogyakarta menunjukkan ada hubungan status gizi dengan perkembangan balita usia 1-3 tahun di Wilayah kerja Puskesmas Jetis Kota Yogyakarta, yang berarti semakin baik gizi balita maka perkembangan balita pun semakin baik ( $p$ value 0,000) (Solechah, 2017).

Hasil penelitian didapatkan bahwa dari 99 balita dengan asupan gizi buruk, sebanyak 60 balita $(60,6 \%)$ memiliki perkembangan yang sesuai. Hal ini kemungkinan disebabkan oleh, tidak selamanya anak yang keburukan energi akan menyebabkan anak langsung mengalami perkembangan motorik yang terlambat dan besarnya faktor genetik dan faktor lingkungan yang lain yang mempengaruhi perkembangan motorik anak. Seperti, faktor lingkungan anak sebelum lahir yaitu adanya keburukan gizi semasa dalam kandungan dan infeksi. Selain itu bisa disebabkan karena anak dalam penelitian ini mengalami perlambatan perkembangan motorik kasar tidak disebabkan oleh asupan energi yang buruk, begitu juga dengan anak yang memiliki perkembangan motorik kasar yang normal, dimana diketahui ada banyak faktor yang berhubungan dengan perkembangan motorik kasar anak.

Banyak faktor penghambat motorik kasar seperti otot-otot tubuh yang tidak berkembang dengan baik sehingga tidak memiliki tenaga yang baik untuk melakukan aktivitas. Jadi walaupun asupan energi pada anak baik, namun otot-otot tubuhnya tidak berkembang dengan baik maka perkembangan motorik kasar anak akan terganggu, karena aktivitas perkembangan motorik kasar dilakukan oleh otot. Maka latihan gerak otot sejak dini dengan mengajak anak bermain sangat diperlukan dalam mengembangkan otot tubuh dalam gerak aktivitas perkembangan motorik kasar. Pada pemeriksaan perkembangan masih ada fokus pada item-item tertentu pada instrument perkembanga yang harus mejadi perhatian.

\section{SIMPULAN}

Distribusi frekuensi balita dengan asupan gizi baik yaitu sebanyak 104 balita $(51,2 \%)$, sedangkan yang asupan gizi buruk sebanyak 99 balita $(48,8 \%)$. Distribusi frekuensi balita dengan pertumbuhan tidak menyimpang yaitu sebanyak 134 balita $(66,0 \%)$, sedangkan yang pertumbuhan menyimpang sebanyak 69 balita $(34,0 \%)$. Distribusi frekuensi balita dengan perkembangan sesuai yaitu sebanyak 142 balita $(70,0 \%)$, sedangkan yang perkembangan tidak sesuai sebanyak 61 balita $(30,0 \%)$. Ada hubungan gizi dengan pertumbuhan balita 1-3 tahun ( $p$ value 0,001, OR 2,8) dan ada hubungan status gizi dengan perkembangan balita 1-3 tahun di Puskesmas Palapa Kota Bandar Lampung tahun 2019 ( $p$ value 0,007, OR 2,4 )

\section{SARAN}

Bagi orang tua diharapkan memberikan asupan gizi sesuai dengan kebutuhan balita, dengan jenis yang beraneka ragam, serta memantau pertumbuhan dan perkembangan secara teratur yaitu setiap bulan dengan aktif mengikuti kegiatan

Setiawati', Megah Rachmawati ${ }^{3 *}$ Program Studi llmu Keperawatan Universitas Malahayati Bandar Lampung.

*Email: Megahrachmawatil@gmail.com

Erna Rahma Yani ${ }^{2}$ Politeknik Kesehatan Kementerian Kesehatan, Malang. Email: erna.rahma_75@yahoo.co.id 
Posyandu. Bagi tenaga kesehatan diharapkan lebih meningkatkan lagi pemantauan terhadap status gizi anak dan melakukan deteksi dini secara rutin terhadap penyimpangan perkembangan anak. Bagi peneliti diharapkan penelitian ini dapat digunakan sebagai dasar untuk penelitian selanjutnya yang berkaitan tentang ketahanan pangan, keluarga, stimulasi, pemanfaatan pelayanan kesehatan dan sanitasi lingkungan yang dihubungkan dengan perkembangan anak

\section{DAFTAR PUSTAKA}

Almatsier, S. (2012). Prinsip dasar ilmu gizi. Gramedia Pustaka Utama.

Azis, M. A. (2018). Gambaran Asupan Nutrisi Dan Status Gizi Balita Di Desa Joho Kecamatan Mojolaban Kabupaten Sukoharjo (Doctoral dissertation, Universitas Muhammadiyah Surakarta).

Harahap, H., Budiman, B., \& Widodo, Y. (2018). Gangguan pertumbuhan dan perkembangan pada anak usia 0, 5-1, 9 tahun terkait dengan asupan makanan dan pengasuhan yang kurang. Gizi Indonesia, 41(1), 49-58.

Indriati, R., \& Murpambudi, Y. K. (2016). Hubungan status gizi dengan perkembangan anak usia 15 tahun di posyandu desa Sirnoboyo Kabupaten Wonogiri. Jurnal IImu Kesehatan Kosala, 4(1).

Jahja, Y. (2011). Psikologi perkembangan. Kencana.

Kementerian Kesehatan Republik Indonesia. (2013). Riset kesehatan dasar (Riskesdas) 2013. Jakarta: Kemenkes RI, 259.

Kementerian Kesehatan Republik Indonesia. (2016). Buku Kesehatan Ibu dan Anak. Kementrian Kesehatan RI dan JICA. Jakarta.

Kementerian Kesehatan Republik Indonesia. (2017). Peraturan Menteri Kesehatan Republik Indonesia Nomor 269. MENKES/PER/III/2008. Rekam Medis. www. depkes. go. id.
Meilani, H., \& Zulaikha, F. (2018). Hubungan antara Status Gizi dengan Kemampuan Personal Sosial pada Anak Pra Sekolah di TK AZ-Zahro Samarinda.

Sapitri, E., Yudiernawati, A., \& Maemunah, N. (2018). Hubungan kemapuan pemberian stimulasi dengan perkembangan motorik halus pada anak prasekolah usia (3-6) tahun di TK Aisyiyah Busnatul Aftal (ABA) 02 Dau Kabupaten Malang. Nursing News: Jurnal IImiah Keperawatan, 3(1).

Setiasih, E.(2011). Analisis faktor faktor yang berhubungan dengan status gizi anak usia (1 5 tahun) di posyandu Cempaka desa Ngrembel kelurahan Gunungpati Kota Semarang.

Soetjiningsih, C. H. (2012). Perkembangan anak sejak pembuahan sampai dengan kanak-kanak akhir. Jakarta: Prenada.

Solechah, M., \& Fitriahadi, E. (2017). Hubungan Status Gizi Dengan Perkembangan Balita Usia 1-3 Tahun Di Wilayah Kerja Puskesmas Jetis Kota Yogyakarta.

Supariasa, I. D. N., \& Nyoman, D. (2012). Pendidikan dan konsultasi gizi. Jakarta: EGC.

Susanty, N. M., \& Margawati, A. (2012). Hubungan Derajat Stunting, Asupan Zat Gizi dan Sosial Ekonomi Rumah Tangga Dengan Perkembangan Motorik Anak Usia 24-36 Bulan di Wilayah Kerja Puskesmas Bugangan Semarang (Doctoral dissertation, Diponegoro University).

Suthutvoravut, U. (2006). Factors associated with dual form of malnutrition in school children in Nakhon Pathom and Bangkok. J Med Assoc Thai, 89(7), 1012-23.

United Nations Children's Fund. (2011). Lookaye Wesena Daruwange Tathwaya-2001. Diakses dari:

https://www.unicef.org/nutrition/files/UNICEF_A nnual_Report_2011_EN_060112.pdf

Setiawati', Megah Rachmawati ${ }^{3 *}$ Program Studi llmu Keperawatan Universitas Malahayati Bandar Lampung. *Email: Megahrachmawatil@gmail.com

Erna Rahma Yani ${ }^{2}$ Politeknik Kesehatan Kementerian Kesehatan, Malang. Email: erna.rahma_75@yahoo.co.id 